B O O K REVIEW

\title{
Africa in International Politics - the interafrican system and its world insertion
}

\author{
by Pio Penna Filho \\ International Relations Institute, University of Brasília
}

\begin{abstract}
(VISENTINI, Paulo Fagundes (2010). A África na Política Internacional O sistema interafricano e sua inserção mundial. Curitiba: Juruá)
\end{abstract}

66 A África na Política Internacional - O sistema interafricano e sua inserção mundial", written by Paulo Fagundes Visentini, full professor of International Relations at the Federal University of Rio Grande do Sul, is an important contribution to both African studies in Brazil and to general knowledge in the field of international relations for the country as a whole. The author, a renowned Brazilian historian and an international relations expert, detains vast academic publications and has been for some time now dedicating himself to the study and analysis of Brazil-Africa relations, the international insertion of African states and the formation and development of the interafrican system itself. Therefore, the book here addressed is the result of years of research and thoughtful consideration from the author upon this theme, which included research field trips to Africa to accomplish this task.

In Brazil, studies - and, consequently, the knowledge and thinking about international relations in Africa - are still modest. It is, in fact, astonishing that in a country with such a territorial dimension as Brazil, long historical ties with the African continent and with a significant presence of afrodescent population, not to mention the enormous and increasing diplomatic, trade, economic and financial interests on "the other side" of the Atlantic, has produced so little about African realities. In this sense, Paulo Visentini's book is a bearer of good news not only for the Brazilian academy but also for a varied and not specialist public. As a matter of fact, the author himself, in the introduction, directs 
the readers of the university-manual format of the book precisely in order to present Africa and its main analytical debates to students, its predominant target audience.

The main objective of the book, as clearly defined on its title, is to analyze the international insertion of African states and the formation of the interafrican system. In order to do so, the author goes through a long trajectory with the aim of demonstrating that the idea of an isolated continent within the international scenario and internally disconnected does not hold true. Furthermore, he observes the vast majority of African leaders have been for a long time paying particular attention to the external context, both as a path to overcome underdevelopment and to obtain legitimacy and support to their governments. Incidentally, the author defends that the search for economic development is a common characteristic among African states since the wave of independency, although he also considers that these states naturally present specific international agendas giving their geographical location and political and economic attributes, among other observable differences within such an ample universe within this continent.

The first two chapters - the first, co-authored with Analúcia Danilevicz Pereira and the second, with Luiz Dario Ribeiro - show precisely the richness of African societies in pre-colonial times, including their interafrican fluxes and intercontinental connections, followed by an analysis of the process of conquest and division of Africa by the Europeans at the end of the $19^{\text {th }}$ century and the slow consolidation of the colonial system, until the decolonization period following World War II. This part of the book, essentially historical, presents a good synthesis of the whole process.

From the third chapter onwards, the author analyzes in detail the emergence and development of the interafrican system and the international insertion of African states. In fact, chapters 3, 4, 5 and 6 can be considered a second and main part of the book as the author analyzes the formation of the African system and the international insertion of new African states at the same time that a periodization is proposed according to his interpretation of the 1960-2009 period, approximately.

Finally, there is a chapter devoted to Brazil-Africa relations. This chapter elaborates a synthesis of the relationship between the two sides of the Atlantic with an emphasis on Brazilian perspectives. The objective is to demonstrate the historical density of this relationship going back to the period Brazil was still a Portuguese colony and that, throughout time, in spite of the rupture observed between the end of slave trade and the de-colonization process in mid-20 $0^{\text {th }}$ century, these relations were restored after the independencies and became denser until they reached a peak during the government of ex-president Lula (2003-2010), producing a qualitative jump from then on and placing Brazil-African relations at a new and unprecedented level. 
The most important contribution of the book for Brazilian scholars lies in the second part, that is, the chapters dealing with the origins, motivations and operations of the African system and the international insertion of these states. This is a relevant emphasis because it is by far the least discussed by Brazilian historians, political scientists and internationalists dedicated to the study of Africa. It is possible to say that before the publication of Paulo Visentini's book, themes like these had only been dealt with in a fragmented manner in few articles, dissertations and thesis by Brazilian authors. Furthermore, the analysis in this book as a whole but especially in this second part, presents the vision and thoughtful consideration of a Brazilian intellectual concerned with the international insertion of African states and their continental relations, a welcome task given his own view on African issues from a Brazilian point of view. For a long time, we have been followers of the visions emanated essentially from the North, especially Europe, incidentally a vision full of prejudice and contaminated by a sense of superiority intrinsic to the colonialism of the metropoles.

It is interesting that even publications that produce a synthesis of Brazil-Africa relations are rare. The exceptions are the renowned work of José Honório Rodrigues (Brasil e África: outro horizonte, published in 1964) and José Flávio Sombra Saraiva (O Lugar da África: a dimensão atlântica da política externa brasileira, de 1946 a nossos dias, published in 1996; and África Parceira do Brasil Atlântico - Relações internacionais do Brasil e da África no início do século XXI, published in 2012). Although the quality of these books is undisputed, there is still a long path for Brazilian academic production to come nearer the profound and complex dimension that links this country to the African continent since its emergence.

Visentini provides a fine context of the decolonization process and the emergence of new African states, revealing their structural fragilities as the result of the colonial domination system and the initial difficulties faced by African leaders, who had to invariably deal with all sort of problems such as the international context of the Cold War and the interventionist practices of powerful nations especially the former metropolitan states. Nevertheless, an in-depth discussion on the nature of these new states and how local elites dealt with legitimacy issues of new governments, especially concerning the domestic base of this legitimacy, are still missing.

A relevant aspect which has not been forgotten by the author refers to the issue of African diversity. Thus, there is a concern to show the diverse experiences and political trajectories of African states, although it is also possible to identify, as the author does, points of convergence and common phases in their political lives. For Visentini, these phases are: a) the ascension to independence; b) the formation of a system of African states; c) the conflicts of the Cold War; d) pacification and marginalization; e) the reinsertion of South 
Africa and the conflictive geopolitical reorganization of Central Africa; and, f) the reaffirmation of Africa.

It is noticeable in the analysis that there is a concern with connecting the political evolution of the African continent with a global level of analysis, that is, the transformation of the international system throughout the Cold War, including its termination by the end of the 1980s, having strong implications for African political life. To some extent, many of the conflicts seen in the continent had an intense external influence.

Among the African regions, Southern Africa received the most detailed attention. This is quite understandable given the fact that the racist and powerful regime of the Republic of South Africa meant, on the one hand, a point of disequilibrium and destabilization for the whole region particularly during the existence of the apartheid regime. On the other hand, however, the actions of South Africa produced a sort of anti-apartheid alignment giving birth to a political action known as the Frontline States, an initial group to the regional integration of Southern Africa. Besides, the late decolonization process of Portuguese colonial areas, the atypical case of Southern Rhodesia, nowadays Zimbabwe, and the progressing external interferences within the context of the Cold War, gave to the region a special connotation.

It is possible to assume that the author sees the Republic of South Africa as an actor that deserves special attention. In fact, the country had and still has an enormous importance to the region. Counting on an industrial economy and connected to the dynamic centers of global capitalism, the South African state counts on a structure not found in any other African actor, neither in the region nor the rest of the continent. Therefore, if the destabilizing power of South Africa was huge, once apartheid was overcome and the country became a de facto democracy and reintegrated in a positive way to interafrican relations, there was a moment of great euphoria with the possibility of South Africa becoming a kind of vector or driver of regional development. Nevertheless, the author argues that the control of South Africa's large capital remaining in the hands of the beneficiaries of the apartheid regime created a tension between a more benevolent political perspective and the permanence of the reality exercise of some degree of regional hegemony.

Another important aspect that deserves attention is the analysis of the more modern stage of the African international insertion. In fact, the author properly analyzes the transition from a period of profound crisis that created a generalized sense of pessimism, typical of the 1990s, to a phase known as "African Renaissance", emerged at the end of the first decade in the post-Cold War era which was followed by a sense of rediscovery of Africa by former metropolitan states, the United States and emerging countries such as China, India and Brazil. Thus, in general terms, the continent starts off the $21^{\text {st }}$ century on the right foot, with positive signs of growth. This fact has also produced a renewal within the 
African system itself, by the replacement of the old Organisation of African Unity (OAU) by the current African Union (UA) among other local schemes and arrangements such as the New Partnership for Africa's Development or NEPAD.

In sum, Paulo Visentini's book presents a great academic merit and it is, for sure, a relevant contribution to a better understanding of the history and, above all, the international relations of the African continent over the last decades. A reader interested in understanding Africa contemporary international relations will have an excellent introduction to the subject with Professor Visentini's book.

Translated by Sandra Gomes 